\title{
USING QSPM AND WASPAS METHODS FOR DETERMINING OUTSOURCING STRATEGIES
}

\author{
Shima LASHGARI ${ }^{1}$, Jurgita ANTUCHEVIČIENÉ ${ }^{2}$, \\ Alireza DELAVARI ${ }^{3}$, Omid KHEIRKHAH ${ }^{4}$ \\ 1,3,4 Tehran University of Medical Sciences, No 49, Italy st. Ghods st. \\ Keshavarz Blvd. Tehran, Iran \\ ${ }^{2}$ Vilnius Gediminas Technical University, Sauletekio al. 11, \\ LT-10223 Vilnius, Lithuania \\ E-mails: ${ }^{1}$ sh.lashgari@farabi.tums.ac.ir; \\ ${ }^{2}$ jurgita.antucheviciene@vgtu.lt (corresponding author); \\ 3delavari@tums.ac.ir; ${ }^{4}$ kheyrkhah@farabi.tums.ac.ir \\ Received 26 February 2014; accepted 23 March 2014
}

\begin{abstract}
The aim of the current study is to select the best strategies for outsourcing development, applying decision-making tools that enable to make reasoned decision. To evaluate outsourcing strategies, a new model of Comprehensive Framework for Strategy Formulation and Selection is presented. Development of outsourcing of healthcare services in Tehran is analysed in the paper. Strengths, Weaknesses, Opportunities, and Threats analysis is used to evaluate the internal and external factors affecting the outsourcing of healthcare services in health deputy of the Tehran University of Medical Sciences in different aspects and to develop several possible outsourcing strategies. Quantitative Strategic Planning Matrix is applied for quantitative evaluation of strategies. It is proposed to validate the approach by applying Multiple Criteria Decision Making methods. Robust and accurate Weighted Aggregated Sum Product Assessment method is selected and applied for quantitative evaluation of strategies. Based on the consistency of the results of the both approaches, the five best strategies to develop healthcare services outsourcing are offered.
\end{abstract}

Keywords: outsourcing, healthcare services, SWOT, QSPM, multiple criteria decision making, WASPAS.

JEL Classification: C44, I11, I18, L24.

\section{Introduction}

Continual and complex changes as well as economic crisis made decision making more difficult. Accordingly, strategic thinking and strategic foresight became more important in these situations (Moon 2013; Jafari, Kazami Movahed 2005; Sarpong et al. 2013). One of the most common strategic solutions in the networked economy is outsourcing (Kang et al. 2012; Liou, Chuang 2010), which assigns non-core competencies and other 
performances of an organization to outside resources (Cheshmberah, Mortazavi 2007), but it is not internal agreement between organizations (Loevinsohn 2008).

All forms of public and private departments in different fields are capable to outsource some of operations, which are not in their value chain (Schniederjans 2005). Based on a recent report, 63, 77, and 63 percent of organizations regarded outsourcing as a primary strategic management tool in 2000, 2006, and 2008 respectively (Kang et al. 2012).

Increasing innovation capacity, economic gain and cost reduction, product and service quality promotion, customer satisfaction, performance improvement, effectiveness, responsiveness improvement and flexibility in front of market fluctuations and customers' demands, skills and technologies acquisition, release internal resources to focus on key functions of organization, and access to human resources expertise are benefits which lead organizations to outsource (Butler, Callahan 2012; Cheshmberah, Mortazavi 2007; Li 2012; Liou, Chuang 2010; Winter, Baguley 2006). Meanwhile, outsourcing helps organization to be agile in cost management through flexible resources, but this agility is not gratis. Agility which is obtained in this way causes risks control loss and potential quality impairment (Anderson et al. 2013).

Outsourcing can cause profound changes in all kinds of public and private organizations such as business, government, medical, educational institutions (Lashgari et al. 2013). Outsourcing of healthcare services in Tehran University of Medical Sciences is analysed in the paper. Since health promotion has the highest priority in a health system, this strategy can be used in different parts of health structure to gain the aim of promotion. The objective of good health has two major components including goodness and fairness (WHO 2000). It has been stated in Iran that health system should have continuous responsibility on the people's life span. These systems must provide required care services for development of healthy individuals, families, and communities (MOHME 2011). The timeliness and accuracy of patient care can be improved by applying nonstandard healthcare systems (Kunstova, Potancok 2013).

Based on the report from the World Health Organization (WHO), providing services, generating the human and physical resources that make service delivery possible, raising and pooling the resources used to pay for health care, and the function of stewardship are four key functions of the health system (WHO 2000). In Iran primary healthcare system has substantially developed since past decades, so that currently more than 95 percent of rural population and about 100 percent of urban population have access to primary healthcare services, and health indicators have improved impressively. However, it is necessary to take major steps to do some reforms in national health system to decrease inequalities in healthcare services, to improve quality of services and users satisfaction (MOHME 2008).

Delivered services to covered area did not have essential productivity, which may be explained by limitation in usage of human and financial resources, low human resource motivation, low quality and efficiency, low responsiveness to service users. Since all health systems obliged about stewardship function, outsourcing is one of the advised solutions to resolve abovementioned problems. 
Based on national rules, the Tehran University of Medical Sciences (TUMS) has outsourced healthcare centers to private sectors named as Associative Healthcare Centers (AHC) since 2006 and was increasing a number of these centers each year. Policy makers expected that the efficiency, cost-effectiveness, performance, inter-sectional coordination, and community involvement could be improved in healthcare services outsourcing (Abolhassani et al. 2009).

Researchers considered necessity of comprehensive revision of this program, evaluating multiple qualitative and quantitative aspects and applying decision-making tools. It is proposed to apply Multi-Criteria Decision Making (MCDM) methods for outsourcing strategies' quantitative evaluation and ranking. Usefulness and applicability of MCDM in economic was proven by Zavadskas and Turskis (2011), Kapliński and Tupenaite (2011) and others. It is suggested to apply a recently developed Weighted Aggregated Sum Product Assessment (WASPAS) method (Zavadskas et al. 2012) in the current research. WASPAS enables to reach the highest accuracy of estimation applying suggested methodology for optimization of weighted aggregated function. It was successfully applied for decision making in business issues with foresight perspective when selecting the best strategies for construction (Zavadskas et al. 2013; Dejus, Antucheviciene 2013), or houses modernization (Staniunas et al. 2013; Šiožinytė, Antuchevičienè 2013), or selecting an appropriate shopping mall location (Hashemkhani Zolfani et al. 2013).

The aim of the current study is to evaluate in different aspects the internal and external factors affecting the outsourcing of healthcare services in health deputy of the TUMS by applying Strengths, Weaknesses, Opportunities, and Threats (SWOT) analysis and to develop possible outsourcing strategies. It is suggested to apply Quantitative Strategic Planning Matrix (QSPM) as well as multiple criteria decision making method WASPAS for quantitative evaluation of strategies. Based on the objective results of the both methods, the best strategies to develop healthcare services outsourcing are offered.

\section{Material and methods of the research}

\subsection{Study design}

The current study is based on deep analysis of the existing situation of the outsourcing of healthcare services in TUMS. For gathering data about status of outsourcing, a questionnaire was designed and was sent to managers and experts related to outsourcing of healthcare services in subordinate units of TUMS. Answers of respondents were analyzed with SPSS software and the extracted information was utilized as strengths, weaknesses, opportunities, and threats that they faced during this project.

To develop the strategies, the model of Comprehensive Framework for Strategy Formulation (CFSF) is used. The CFSF model is shown in Figure 1. This model has tools and methods which are useful for various organizations with different sizes. Also, it helps strategists to identify, evaluate, and select priority strategies. CFSF has four stages including: 1) Initiating stage, 2) Input stage, 3) Matching stage, and 4) Decision making stage. 


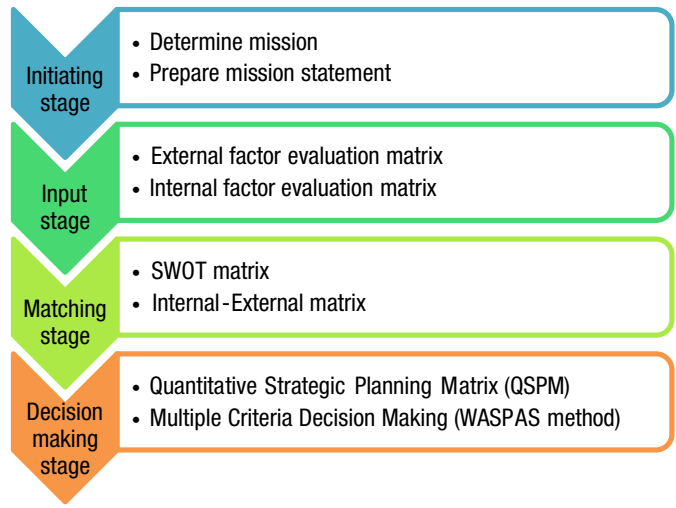

Fig. 1. Comprehensive framework for strategy formulation and selection

In the current study for the internal and external factor evaluation, following steps were taken: first, final list of internal and external environmental factors which support the views of experts was provided, and then a weight was allocated for each factor. In the next step, scores from 1 to 4 were given to each factor according to answers of respondents and then weight scores were calculated. As a result of external factor evaluation (EFE) and internal factor evaluation (IFE) matrixes, the encounter point in internalexternal matrix was obtained where the coordinate of organization in this matrix is and what kind of strategies are appropriate for it. Based on this, the appropriate strategies were prepared for outsourcing of healthcare services. And eventually to determine the best strategies and to prioritize them QSPM (A'arabi et al. 2010; Beidokhty Nejad et al. 2011) and WASPAS (Zavadaskas et al. 2012) methods were used.

This research was done in the health deputy of Tehran University of Medical Sciences and its subordinate units including south of Tehran, Rey and Eslamshahr health networks.

\subsection{Questionnaire}

Data collection was done through the questionnaire entitled 'Strengths, weaknesses, opportunities, and threats in outsourcing of healthcare services in AHC'. Likert-type scale was used in the scoring of 71 questions and the remaining 14 questions of the questionnaire were open-ended. Questions were divided into four main parts: customer, contractor, employer and its affiliated unity, and other organizations. There were 9 questions related to customer. Also, there were 35 questions about contractor which were categorized into 5 groups included: 1) Physical environment, 2) Equipment and consumables, 3) Human resources, 4) Services, and 5) others. Moreover, there were 35 questions related to employer and its affiliated unity. This part of questions was categorized into 6 groups including: 1) Supervision, 2) Remuneration, 3) Learning at work, 4) Terms and conditions, 5) Consumables and medicine, and 6) others. Also, there were 6 questions about other organizations. 


\subsection{Reliability and validity measurement of questionnaire}

Questionnaire was designed by using two Master of Public Health theses (Ghayomzade 2011; Salmani Nadoshan 2010) and technical viewpoints of experts. Content validity ratio (CVR) and content validity index (CVI) were used to evaluate the validity of the questionnaire. The questionnaire was sent to eight experts in the field of research and health sciences. The questionnaire was revised based on the expert panel's comments and was sent back to them. Result of the second evaluation showed that CVR of 71 questions with Likert criteria was 75 percent and four questions from basic questionnaire with CVR of less than 75 percent were omitted. The second evaluation of CVI was equal to 0.87 , which was higher than the standard rate $(\mathrm{CVI}>0.79)$.

From 22 eligible subjects to evaluate reliability, 20 persons answered the questionnaire. The internal consistency was used in order to calculate the reliability. The Cronbach's alpha was equal to 0.80 which was higher than standard rate $(\alpha>0.70)$.

\subsection{Data analysis of questionnaire}

The analysis of the questionnaire was categorized into two types: 1) Opportunity or strength and 2) Threat or weakness.

From the view point of opportunity or strength, if the option 'Completely agree' got the highest score, it would classify as 'Special'. If the option 'Agree' got the highest score, it would classify as 'Common'. If the difference between options 'Completely agree' and 'Agree' was less than 10 percent, that item classified as 'Common'. Otherwise the item was omitted.

From the view point of threat or weakness, if the option 'Completely disagree' got the highest score, it would classify as 'Serious'. If the option 'Disagree' got the highest score, it would classify as 'Common'. If the difference between options 'Completely disagree' and 'Disagree' was less than 10 percent, that item classified as 'Common'. Otherwise the item was omitted.

\section{Development and evaluation of outsourcing strategies}

Development of outsourcing strategies and their evaluation is made following the stages of the proposed Comprehensive Framework for Strategy Formulation and Selection (Fig. 1).

\subsection{Initiating stage}

The mission designing is the initiating stage of the Comprehensive Framework for Strategy Formulation, and it is encompassing 9 items including product, customer, market, technology, growth and profitability, philosophy, distinctive competency, people imagination and staff care. Mission statement of healthcare outsourcing in this university is as follows:

Main mission in healthcare outsourcing program in health deputy of the Tehran University of Medical Sciences is increasing accessibility of health services. This deputy 
wants to deliver two kinds of services with implementation of this program. These services included:

- Common services such as population census, volunteers' attraction, health training in different levels of society which is appropriate for needs of individuals.

- Specific services such as prenatal and postnatal care, child care, student care, family planning, immunization and screening.

These services are predicted for covered population of this university, which are 2690674 people according to 2006 population and housing census of statistical center of Iran.

It is the responsibility of this deputy to deliver services in the closest place for this population who live in some municipality area of south of Tehran, also in Rey and Eslamshar city.

Service delivery must follow the protocols of the Ministry of Health and Medical Education and the standards which are determined by health deputy of this university and this deputy should make necessary supervision.

Survival of this program is related to national macro policies in the cases of health and treatment. Promotion of the services' quality and quantity, adherence to protocols and standards of delivery services, service recipients' satisfaction, providing of financial resources, and new services' deliveries are required for survival of the program. The government is responsible to provide healthcare services and especially primary healthcare free to the public. Since the Tehran University of Medical Sciences has the stewardship of healthcare services, this program does not concern profits; instead of public health promotion also it is the ultimate goal of profitability of such programs.

Respect of healthcare outsourcing program stakeholders' rights includes covered population, contractors, employees, and government. Health deputy always considers providing stakeholders satisfaction.

Although, making such a space for providing high quality and standard services and developing sense of empathy and cooperation between private and governmental organizations is another philosophy of healthcare outsourcing program.

Healthcare outsourcing is done to increase output, cost-effectiveness, and performance which are important in primary health care and promote accessibility, quality, and coverage.

Forasmuch as geographic location of providing services of this university is considered as low-income areas, these free services are welcomed by residents of these areas.

In addition, because of people's old opinion about governmental health centers, people may have the same viewpoints about private centers which are under supervision of university.

It is worth to note that healthcare outsourcing identity is from the staffs which work in, so health deputy tries to hire and preserve experts in health services. As well, health deputy tries to provide peaceful work-life and satisfaction feeling from service production for staffs. Health deputy pursues justices of staffs from contractors of outsourcing. 


\subsection{Input stage}

Extracted opportunities, threats, strengths, and weaknesses from questionnaire are classified by using external and internal factor evaluation matrixes. Classifying bases of opportunities and threats are cases such as political-legal factors, customers, providers, and existing competitors. For classifying strengths and weaknesses cases such as organizational-managerial, financial-accounting, manufacturing-operational, researchdevelopment, human resource, marketing and management information system factors are used. Opportunities and threats of outsourcing of healthcare services are identified and evaluated based on questionnaire and following experts' judgments (Table 1).

Internal factors of outsourcing of healthcare services capabilities are identified and evaluated in Table 2.

Table 1. External factor evaluation matrixes

\begin{tabular}{|c|c|c|c|}
\hline Opportunities & \multirow{2}{*}{ Weight } & \multirow{2}{*}{ Rating } & \multirow{2}{*}{$\begin{array}{l}\text { Weighted } \\
\text { score }\end{array}$} \\
\hline Political-legal factors & & & \\
\hline & 1 & 2 & 3 \\
\hline $\begin{array}{l}\text { O1: Positive vision of different level managers of organization } \\
\text { about health care outsourcing }\end{array}$ & 0.06 & 4 & 0.24 \\
\hline O2: Limitations of organization in manpower employment & 0.04 & 4 & 0.16 \\
\hline $\begin{array}{l}\text { O3: Limitations of organization in increase or decrease } \\
\text { administrative structure }\end{array}$ & 0.04 & 4 & 0.16 \\
\hline $\begin{array}{l}\text { O4: Limitations of organization in purchase and construct } \\
\text { of governmental building }\end{array}$ & 0.04 & 4 & 0.16 \\
\hline $\begin{array}{l}\text { O5: Positive vision of Ministry of Health and Medical Education } \\
\text { (MOHME) about health care outsourcing }\end{array}$ & 0.05 & 4 & 0.20 \\
\hline O6: Discuss the issue of AHCs in Parliament & 0.04 & 4 & 0.16 \\
\hline \multicolumn{4}{|l|}{ Consumer factors } \\
\hline O7: People's requirement to services of AHCs & 0.05 & 4 & 0.20 \\
\hline O8: People's confidence to AHCs & 0.04 & 4 & 0.16 \\
\hline O9: People's reception to AHCs and their services & 0.04 & 3 & 0.12 \\
\hline O10: Increase people's satisfaction through outsourcing & 0.05 & 3 & 0.15 \\
\hline O11: Change population pattern and new needs of urbanization & 0.04 & 4 & 0.16 \\
\hline \multicolumn{4}{|l|}{ Provider factors } \\
\hline O12: Potential of private sector in service delivery & 0.02 & 3 & 0.06 \\
\hline \multicolumn{4}{|l|}{ Threats } \\
\hline \multicolumn{4}{|l|}{ Political-legal factors } \\
\hline $\begin{array}{l}\text { T1: Absence of ensure about continuity of outsourcing } \\
\text { of healthcare program in organization }\end{array}$ & 0.10 & 1 & 0.10 \\
\hline
\end{tabular}


End of Table 1

\begin{tabular}{|c|c|c|c|}
\hline & 1 & 2 & 3 \\
\hline \multicolumn{4}{|l|}{ Consumer factors } \\
\hline $\begin{array}{l}\text { T2: Crowded supportive centers (governmental } \\
\text { healthcare centers) }\end{array}$ & 0.01 & 2 & 0.02 \\
\hline $\begin{array}{l}\text { T3: Difficult access for elderly people and pregnant women to } \\
\text { the AHCs in top floors in a building without elevator }\end{array}$ & 0.02 & 2 & 0.04 \\
\hline T4: Inappropriate physical space of some AHCs & 0.02 & 2 & 0.04 \\
\hline T5: Unwillingness of some volunteers to cooperate with AHCs & 0.01 & 2 & 0.02 \\
\hline T6: Inability to attract the participation of some of the volunteers & 0.01 & 2 & 0.02 \\
\hline \multicolumn{4}{|l|}{ Provider factors } \\
\hline T7: Rental buildings and need to change them every year & 0.05 & 1 & 0.05 \\
\hline T8: Increase rent for building & 0.05 & 1 & 0.05 \\
\hline T9: Delay in paying staff salaries off AHCs & 0.05 & 1 & 0.05 \\
\hline T10: Lack of staff encouragement by contractors of AHCs & 0.02 & 2 & 0.04 \\
\hline $\begin{array}{l}\text { T11: Decrease effectiveness of educational programs because } \\
\text { casual changes of AHCs' staffs }\end{array}$ & 0.03 & 1 & 0.03 \\
\hline T12: Loss of experience of AHCs' staffs because casual changes & 0.02 & 1 & 0.02 \\
\hline \multicolumn{4}{|l|}{ Existing competitor factors } \\
\hline $\begin{array}{l}\text { T13: Deliver services by private specialists and people's } \\
\text { tendency to refer to them }\end{array}$ & 0.10 & 1 & 0.10 \\
\hline Total score & & & 2.51 \\
\hline
\end{tabular}

Table 2. Internal factor evaluation matrixes

\begin{tabular}{lccc}
\hline \multicolumn{1}{c}{ Strengths } & Weight & Rating & $\begin{array}{c}\text { Weighted } \\
\text { score }\end{array}$ \\
\hline \multicolumn{1}{c}{ Organization and management factors } & 1 & 2 & 3 \\
\hline \multicolumn{1}{c}{ Accounting and financial factors } & 0.04 & 4 & 0.16 \\
\hline S1: Availability of clear guidelines of outsourcing healthcare & 0.04 & 4 & 0.16 \\
\hline S2: Increase accessibility of covered population & & & \\
\hline \multicolumn{1}{c}{ Research and development factors } & 0.03 & 3 & 0.09 \\
\hline S3: Decrease overload costs & & & \\
\hline Production and operation factors & 0.06 & 4 & 0.24 \\
\hline S4: Improve service delivery & & & 0.04 \\
\hline $\begin{array}{l}\text { S5: Promote indicators of health programs in association with } \\
\text { outsourcing healthcare }\end{array}$ & & & \\
\hline & & & 0.08 \\
\hline $\begin{array}{l}\text { S6: Design purposeful education since hiring and in-service } \\
\text { human resource }\end{array}$ & 0.02 & 4 & \\
\hline
\end{tabular}


End of Table 2

\begin{tabular}{llll}
\hline & 1 & 2 & 3 \\
\hline \multicolumn{1}{c}{ Human resource factors } & & & \\
\hline S7: Improved supervision by experts & 0.02 & 4 & 0.08 \\
\hline S8: Pay supervision remuneration to experts & 0.02 & 4 & 0.08 \\
\hline S9: Utilize adequate experts for supervise AHCs & 0.01 & 3 & 0.03 \\
\hline S10: Create job for graduates of health sciences in AHCs & 0.03 & 4 & 0.12 \\
\hline
\end{tabular}

\section{Weaknesses}

Organization and management factors

\begin{tabular}{llll}
\hline $\begin{array}{l}\text { W1: Low job security of AHCs' staffs compared to governmental } \\
\text { centers' staffs }\end{array}$ & 0.07 & 1 & 0.07 \\
\hline $\begin{array}{l}\text { W2: Low salary of AHCs' staffs compared to governmental } \\
\text { centers' staffs }\end{array}$ & 0.07 & 1 & 0.07 \\
\hline W3: Care too much about bureaucracy and documentation & 0.03 & 2 & 0.06 \\
\hline W4: Low amount of outsourcing contract & 0.07 & 1 & 0.07 \\
\hline W5: Lack of clear insurance instructions & 0.02 & 2 & 0.04 \\
\hline $\begin{array}{l}\text { W6: Lack of Health Deputy response for AHCs' staffs complaint } \\
\text { about their insurance }\end{array}$ & 0.03 & 1 & 0.03 \\
\hline
\end{tabular}

\begin{tabular}{|c|c|c|c|}
\hline \multicolumn{4}{|l|}{ Marketing factors } \\
\hline W7: Unable advertising about healthcare according to law & 0.04 & 1 & 0.04 \\
\hline \multicolumn{4}{|l|}{ Accounting and financial factors } \\
\hline W8: Delay in financial obligation payment to AHCs contractors & 0.04 & 2 & 0.08 \\
\hline \multicolumn{4}{|l|}{ Production and operation factors } \\
\hline $\begin{array}{l}\text { W9: Low quality and dissatisfaction of people about service } \\
\text { delivery of supportive centers (governmental health centers) }\end{array}$ & 0.04 & 2 & 0.08 \\
\hline \multicolumn{4}{|l|}{ Research and development factors } \\
\hline $\begin{array}{l}\text { W10: Lack of clarity in the referring process when getting more } \\
\text { specialized services }\end{array}$ & 0.04 & 2 & 0.08 \\
\hline W11: Lack of opportunity for consultive and educational services & 0.04 & 2 & 0.08 \\
\hline W12: High volume of work in AHCs & 0.03 & 2 & 0.06 \\
\hline W13: Time consuming of completing supervision checklists & 0.02 & 2 & 0.04 \\
\hline W14: Compressed time of educating staffs & 0.02 & 2 & 0.04 \\
\hline \multicolumn{4}{|l|}{ Management information system factors } \\
\hline W15: Lack of automation system for office communications & 0.03 & 1 & 0.03 \\
\hline W16: Lack of management information system & 0.04 & 1 & 0.04 \\
\hline \multicolumn{4}{|l|}{ Human resource factors } \\
\hline $\begin{array}{l}\text { W17: Obedience of AHCs' staff due to concerns about } \\
\text { unemployment }\end{array}$ & 0.04 & 1 & 0.04 \\
\hline W18: Promote supervising skills of experts & 0.02 & 2 & 0.04 \\
\hline Total score & & & 2.15 \\
\hline
\end{tabular}


Also analyzing the information extracted from questionnaire, opportunities and strengths were divided in two grades of special and common, and threats and weaknesses were divided in two grades of serious and common. On the next phase, 200 numbers were allocated to opportunity and threat items and as well 200 numbers to strength and weakness items. Then numbers of each one were multiplied to grade of each one and each factor got a rate. Total rate in external factor evaluation matrix was 2.51 . When the rate of this matrix was higher than 2.50, it was predicted that ahead opportunities overcome the threats in healthcare outsourcing program. On the other hand, total rate of internal factor evaluation matrix was 2.13 , and because it was lower than 2.50 , it was predicted that weaknesses of this program are dominant over strengths.

\subsection{Matching stage}

Based on total score of Tables 1 and 2, the encounter point of these two values is organization's appropriate strategies (the situation) of healthcare outsourcing program in health deputy of TUMS (Fig. 2).

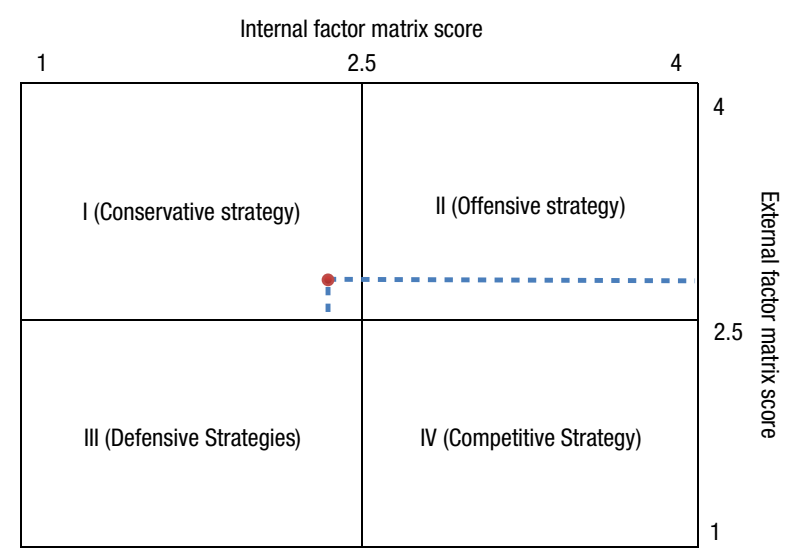

Fig. 2. Internal-external matrix

Also, using SWOT matrix 15 strategies were designed for healthcare outsourcing, including 4 SO strategies, 6 WO strategies, 3 ST strategies and 2 WT strategies (Table 3).

\subsection{Decision making stage}

Outcomes of previous stages of the Comprehensive Framework for Strategy Formulation and Selection (Fig. 1) are used. Strategic options are evaluated applying usual QSPM tool in the first step of the current stage. Evaluation scores, i.e. attractiveness scores for strategic options are presented in Table 4.

Next the new approach for strategic options' evaluation is suggested. Initial data from QSPM is used and calculations applying Multiple Criteria Decision Making tool, namely WASPAS method (Zavadskas et al. 2012) are performed. 

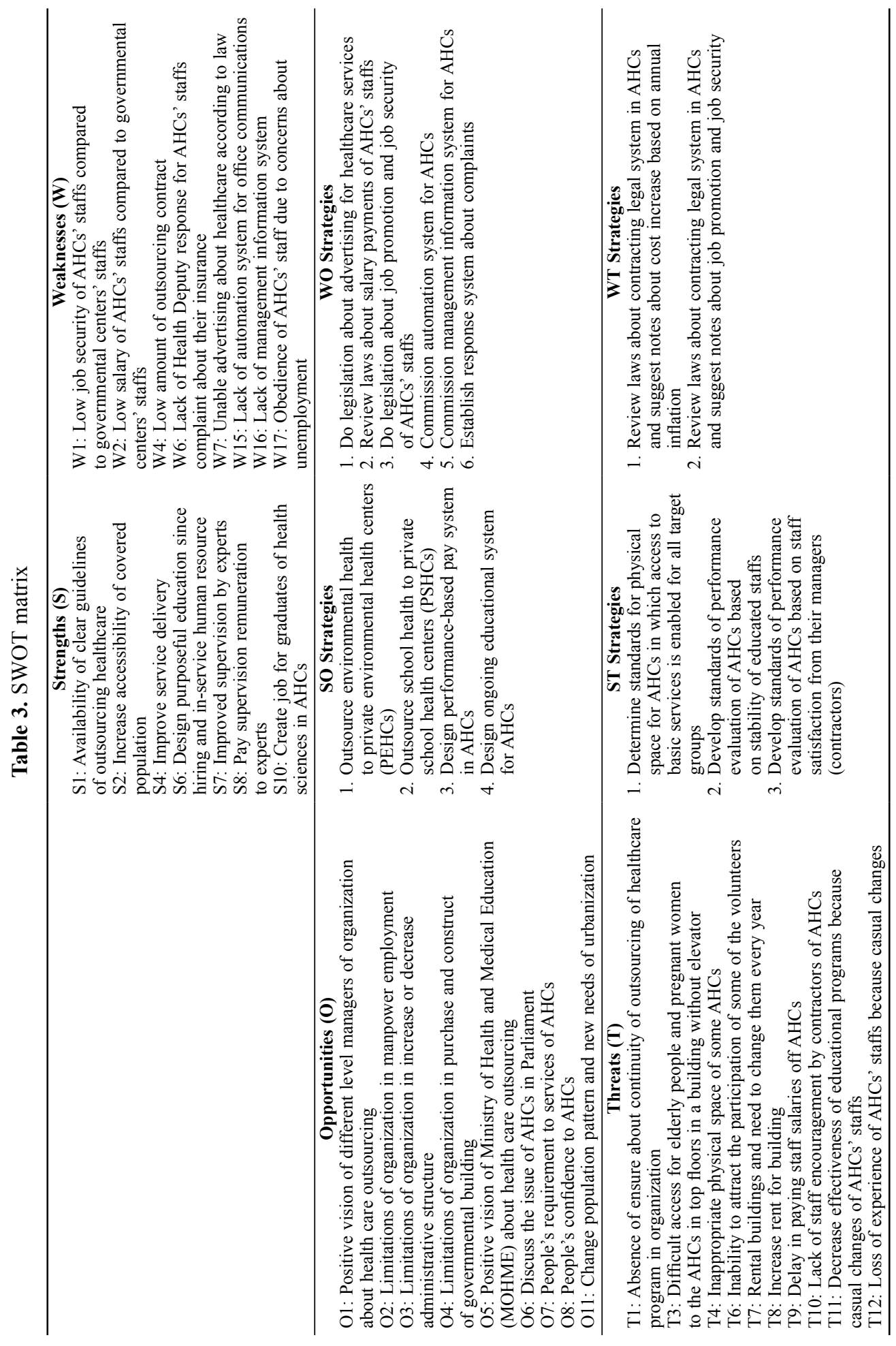
Suppose that a given MCDM problem is defined on $m$ alternatives (strategic options) and $n$ decision criteria (internal and external factors). Next suppose that $w_{j}$ denotes the relative significance (weight) of the criterion; and $x_{i j}$ is the performance value of alternative $i$ when it is evaluated in terms of criterion $j$. An integrated value of utility function $Q_{i}$ of each alternative is called the Weighted Aggregated Sum Product Assessment (WASPAS):

$$
Q_{i}=\lambda \sum_{j=1}^{n} \bar{x}_{i j} w_{j}+(1-\lambda) \prod_{j=1}^{n}\left(\bar{x}_{i j}\right)^{w_{j}}, \lambda=0, \ldots, 1, i=1,2, . ., m ; j=1,2, \ldots, n,
$$

where linear normalization of initial criteria values is applied:

$$
\bar{x}_{i j}=\frac{x_{i j}}{\max _{i} x_{i j}} \text { or } \bar{x}_{i j}=\frac{\min _{i} x_{i j}}{x_{i j}},
$$

if $\max _{i} x_{i j}$ value or $\min _{i} x_{i j}$ is preferable, respectively.

Methodology for optimization of weighted aggregated utility function when calculating the optimal values of coefficient $\lambda$ was proposed, that enabled to reach the highest accuracy of estimation (Zavadskas et al. 2012).

In the current case accuracy of initial criteria is not evaluated dealing with uncertainty in decision environment. For future calculations a simplified WASPAS method (Hashemkhani Zolfani et al. 2013; Zavadskas et al. 2013) is applied, assuming that $\lambda=0.5$. Then an integrated value of utility function for each alternative is determined as follows:

$$
Q_{i}=0.5 \sum_{j=1}^{n} \bar{x}_{i j} w_{j}+0.5 \prod_{j=1}^{n}\left(\bar{x}_{i j}\right)^{w_{j}}, i=1,2, . ., m ; j=1,2, \ldots, n .
$$

Calculated integrated values of utility functions for each alternative under consideration are presented in Table 4. Strategic options are ranked according to values of their utility function, from the highest to the lowest value respectively.

Strategies which have gotten the highest score in successful using of internal and external factors as well as alternatives with the highest relative significance are determined. The 5 best ranked outsourcing strategies with the highest score are as follows:

1. Review laws about contracting legal system in AHCs and suggest notes about cost increase based on annual inflation;

2. Review laws about contracting legal system in AHCs and suggest notes about job promotion and job security;

3. Establish response system about complaints;

4. Do legislation about job promotion and job security of AHCs' staffs;

5. Review laws about salary payments of AHCs' staffs.

Planners and politicians can determine priorities of organization and the best strategies by concerning the scores of these two methods. 
Table 4. Evaluation of strategic options

\begin{tabular}{lcccccc}
\hline $\begin{array}{c}\text { Strategic } \\
\text { options } \\
\text { (decision } \\
\text { alternatives) }\end{array}$ & $\begin{array}{c}\text { Total rate } \\
\text { of external } \\
\text { factors }\end{array}$ & $\begin{array}{c}\text { Total rate } \\
\text { of internal } \\
\text { factors }\end{array}$ & $\begin{array}{c}\text { Attractive- } \\
\text { ness scores }\end{array}$ & $\begin{array}{c}\text { External } \\
\text { factors' } \\
\text { evaluation }\end{array}$ & $\begin{array}{c}\text { Internal } \\
\text { factors' } \\
\text { evaluation }\end{array}$ & $\begin{array}{c}\text { Value of } \\
\text { utility } \\
\text { function } Q_{i}\end{array}$ \\
\cline { 2 - 7 } Option 1 & 2.17 & 1.41 & 3.58 & 0.5054 & 0.3341 & 0.4198 \\
\hline Option 2 & 2.43 & 2.18 & 4.61 & 0.5748 & 0.5103 & 0.5426 \\
\hline Option 3 & 2.39 & 2.23 & 4.62 & 0.5648 & 0.5214 & 0.5431 \\
\hline Option 4 & 2.12 & 2.05 & 4.17 & 0.4973 & 0.4861 & 0.4917 \\
\hline Option 5 & 2.19 & 2.14 & 4.33 & 0.5155 & 0.5056 & 0.5106 \\
\hline Option 6 & 2.54 & 2.21 & 4.75 & 0.6051 & 0.5258 & 0.5654 \\
\hline Option 7 & 2.19 & 1.62 & 3.84 & 0.5169 & 0.3835 & 0.4502 \\
\hline Option 8 & 2.19 & 1.75 & 3.94 & 0.5169 & 0.4060 & 0.4614 \\
\hline Option 9 & 2.42 & 2.00 & 4.42 & 0.5796 & 0.4749 & 0.5272 \\
\hline Option 10 & 2.27 & 1.78 & 4.05 & 0.5388 & 0.4206 & 0.4797 \\
\hline Option 11 & 2.26 & 1.52 & 3.78 & 0.5391 & 0.3570 & 0.4480 \\
\hline Option 12 & 2.36 & 1.56 & 3.92 & 0.5626 & 0.3707 & 0.4667 \\
\hline Option 13 & 2.36 & 1.71 & 4.07 & 0.5626 & 0.4000 & 0.4813 \\
\hline Option 14 & 2.56 & 2.17 & 4.82 & 0.6322 & 0.5010 & 0.5666 \\
\hline Option 15 & 2.57 & 2.19 & 4.76 & 0.6078 & 0.5068 & 0.5573 \\
\hline & & & & & & \\
\hline
\end{tabular}

\section{Conclusions}

To evaluate outsourcing strategies, a new model of Comprehensive Framework for Strategy Formulation and Selection is developed. For ranking strategic options and selecting the best strategy it is suggested to supplement a decision making stage of the Framework with multiple criteria WASPAS method.

The current study is based on deep analysis of the internal and external factors affecting the outsourcing of healthcare services in health deputy of the Tehran University of Medical Sciences. Calculated total rate in external factor evaluation (EFE) matrix is 2.51. When the rate of this matrix is higher than 2.50, it is predicted that ahead opportunities overcome the threats in healthcare outsourcing program. On the other hand, total rate of internal factor evaluation (IFE) matrix is 2.13 , and because it is lower than 2.50 , it is predicted that weaknesses of this program are dominant over strengths.

15 different strategies are developed for healthcare outsourcing. It is suggested to evaluate strategic options applying integrated approach that combines QSPM tool and also Multiple Criteria Decision Making tool, namely WASPAS method.

It should be noted that the first five best ranked strategic options coincide applying QSPM as well as WASPAS approaches. Also, the result may be considered being accurate and reliable, because a robust, mathematically based WASPAS method was applied. 


\section{References}

A'arabi, S. M.; Aghazade, H.; Nezamivand Chegini, H. 2010. A handbook of strategic planning. Iran, Tehran: Cultural Research Bureau.

Abolhassani, F.; Ghanbari, A.; Salmani Nadoshan, M. R. 2009. Outsourcing health services. Tehran: Pooneh.

Anderson, M.; Asdemir, O.; Tripathy, A. 2013. Use of precedent and antecedent information in strategic cost management, Journal of Business Research 66(5): 643-650.

http://dx.doi.org/10.1016/j.jbusres.2012.08.021

Beidokhty Nejad, M.; Pouyan, N.; Shojaee, M. R. 2011. Applying TOPSIS and QSPM methods in framework SWOT model: case study of the Iran's stock market, Australian Journal of Business and Management Research 1(5): 93-103.

Butler, M. G.; Callahan, C. M. 2012. Human resource outsourcing: market and operating performance effects of administrative HR functions, Journal of Business Research 67(2): 218-224. http://dx.doi.org/10.1016/j.jbusres.2012.09.026

Cheshmberah, M.; Mortazavi, S. M. 2007. Effectiveness outsourcing management. Tehran, Iran: Ketabe Mehraban Nashr Agency.

Dejus, T.; Antucheviciene, J. 2013. Assessment of health and safety solutions at a construction site, Journal of Civil Engineering and Management (19)5: 728-737.

http://dx.doi.org/10.3846/13923730.2013.812578

Ghayomzade, M. R. 2011. Barriers and facilitators of participatory and public health services at sites covered by Tehran University of Medical Sciences.Partial Fulfillment of the Requirements for the Degree of Master of Public Health. The Tehran University of Medical Sciences, Tehran, Iran.

Hashemkhani Zolfani, S.; Aghdaie, M. H.; Derakhti, A.; Zavadskas, E. K.; Morshed Varzandeh, M. H. 2013. Decision making on business issues with foresight perspective; an application of new hybrid MCDM model in shopping mall locating, Expert Systems with Applications 40(17): 7111-7121. http://dx.doi.org/10.1016/j.eswa.2013.06.040

Jafari, M.; Kazami Movahed, M. 2005. Strategic thinking and change management, international perspective on organizational dynamics. Tehran: Rasa Cultural Services Agency.

Kang, M.; Wu, X.; Hong, P.; Park, Y. 2012. Aligning organizational control practices with competitive outsourcing performance, Journal of Business Research 65(8): 1195-1201.

http://dx.doi.org/10.1016/j.jbusres.2011.07.004

Kapliński, O.; Tupenaite, L. 2011. Review of the multiple criteria decision making methods, intelligent and biometric systems applied in modern construction economics, Transformations in Business \& Economics 10(1): 166-181.

Kunstova, R.; Potancok, M. 2013. How to measure benefits of non-standard healthcare systems, Inzinerine Ekonomika - Engineering Economics 24(1): 119-125.

Lashgari, Sh.; Delavari, A. R.; Kheirkhah, O.; Antucheviciene, J. 2013. The impact of outsourcing in terms of access and quality of health services from participants attitude, Inzinerine Ekonomika - Engineering Economics 24(4): 356-363.

Li, J. J. 2012. The alignment between organizational control mechanisms and outsourcing strategies: a commentary essay, Journal of Business Research 65(9): 1384-1386.

http://dx.doi.org/10.1016/j.jbusres.2011.09.020

Liou, J. J. H.; Chuang, Y. 2010. Developing a hybrid multi-criteria model for selection of outsourcing providers, Expert Systems with Applications 37(5): 3755-3761.

http://dx.doi.org/10.1016/j.eswa.2009.11.048

Loevinsohn, B. 2008. Performance-Based Contracting for Health Services in Developing Countries: a Toolkit. Washington: The International Bank for Reconstruction and Development / The World Bank.

MOHME (Ministry of Health and Medical Education). 2008. Health and social determining factors, the main concept of equity in health and fair opportunity for all. Tehran, Iran: Movafagh publication. 
MOHME (Ministry of Health and Medical Education). 2011. IR Iran Health reform plan based on the model of Islamic - Iran's progress. Tehran, Iran.

Moon, B.-J. 2013. Antecedents and outcomes of strategic thinking, Journal of Business Research 66(10): 1698-1708. http://dx.doi.org/10.1016/j.jbusres.2012.11.006

Salmani Nadoshan, M. R. 2010. Check the quality and standard of service provided by the associative healthcare centers and satisfaction with the service provided for covered population of Tehran University of Medical Sciences and compare public and private sectors in 1388. Partial fulfillment of the requirements for the degree of Master of Public Health. The Tehran University of Medical Sciences, Tehran, Iran.

Sarpong, D.; Maclean, M.; Davies, C. 2013. A matter of foresight: How practices enable (or impede) organizational foresightfulness, European Management Journal 31(6): 613-625.

http://dx.doi.org/10.1016/j.emj.2013.03.004

Schniederjans, M. J. 2005. Focused issue on operations research and outsourcing, Computers \& Operations Research 32(9): 2493-2494.

Staniunas, M.; Medineckiene, M.; Zavadskas, E. K.; Kalibatas, D. 2013. To modernize or not: ecological-economical assessment of multi-dwelling houses modernization, Archives of Civil and Mechanical Engineering 13(1): 88-98. http://dx.doi.org/10.1016/j.acme.2012.11.003

Šiožinytė, E.; Antuchevičienè, J. 2013. Solving the problems of daylighting and tradition continuity in a reconstructed vernacular building, Journal of Civil Engineering and Management 19(6): 873-882. http://dx.doi.org/10.3846/13923730.2013.851113

Winter, J. E.; Baguley, J. 2006. Outsourcing Clinical Development-Strategies for Working with CROs and Other Partners. Co-published in association with the Pharmaceutical Contract Management Group. Hampshire: Gower Publishing Limited.

WHO. 2000. The World health report 2000: health systems: improving performance. Geneva: World Health Organization.

Zavadskas, E. K.; Turskis, Z. 2011. Multiple criteria decision making (MCDM) methods in economics: an overview, Technological and Economic Development of Economy 17(2): 397-427. http://dx.doi.org/10.3846/20294913.2011.593291

Zavadskas, E. K.; Antucheviciene, J.; Saparauskas, J.; Turskis, Z. 2013. MCDM methods WASPAS and MULTIMOORA: verification of robustness of methods when assessing alternative solutions, Economic Computation and Economic Cybernetics Studies and Research 47(2): 5-20.

Zavadskas, E. K.; Turskis, Z.; Antucheviciene, J.; Zakarevicius, A. 2012. Optimization of weighted aggregated sum product assessment, Electronics and Electrical Engineering - Elektronika ir Elektrotechnika 6(122): 3-6.

Shima LASHGARI is an expert in Executive Affairs in Tehran University of Medical Sciences, Islamic Republic of Iran. Executive affairs and research in related fields are her interests.

Jurgita ANTUCHEVIČIENE் is Associate Professor at the Department of Construction Technology and Management, Vilnius Gediminas Technical University, Lithuania. Research interests are: sustainable development, construction business management and investments, multiple criteria analysis, decision-making theories and decision support systems.

Alireza DELAVARI is Associate Professor of Internal Medicine in Tehran University of Medical Sciences, Islamic Republic of Iran, and Faculty member of Digestive Diseases Research Center in Tehran University of Medical Sciences. Policy making in Ministry of Health and Medical Education (MOHME) and research are fields in which he considers. He is an author of number of papers in area of medical sciences and also he is a member of number of medical sciences societies and committees.

Omid KHEIRKHAH is Executive vice of Health affairs, Tehran University of Medical Sciences, Islamic Republic of Iran. Executive affairs and research in medical sciences and also executive fields are his interests. He is a co-author of number of books in area of medical sciences and software. 